\title{
Pengenalan Teknik Molekuler Polymerase Chain Reaction (PCR) pada Guru Biologi SMA Di Kota Mataram
}

\author{
Eustachius Hagni Wardoyo*, Yunita Sabrina, Dewi Suryani \\ Fakultas Kedokteran Universitas Mataram, Kota Mataram, Indonesia
}

\begin{abstract}
Kata Kunci: pelatihan PCR, teknik molekuler

Abstrak: Teknik molekuler polymerase chain reaction (PCR) merupakan teknik dasar amplifikasi materi genetik dan protein yang sangat bermanfaat dalam bidang biologi, kedokteran, pertanian dan bidang lain. PCR digunakan dalam identifikasi kelainan genetik, diagnosis mikrobiologi, sekuensing DNA, identifikasi forensik dan masih banyak lagi. Dasar dasar biomolekuler dan teknik PCR ini tertuang dalam kurikulum SMA untuk siswa kelas 3 SMA. Melihat adanya kesenjangan belum terpaparnya semua guru SMA di kota Mataram dengan teknik PCR ini maka perlu dilakukan pengenalan teknik PCR bagi guru SMA dengan harapan akan membantu guru dalam mengimplementasikan materi ini ke dalam pelajaran biologi SMA. Dalam pelatihan ini guru biologi sebagai salah satu perantaraan pembelajaran utama siswa SMA diperkenalkan teknik ini secara Hands-On. Sebanyak 12 guru yang mewakili 12 SMA di kota Mataram ikut serta dalam pelatihan ini. Pengenalan teknik PCR dilakukan dalam dua fase: presentasi di kelas dan demonstrasi di laboratorium. Presentasi dikelas menjelaskan dasar materi genetik dan teknik PCR dan dilanjutkan dengan demonstrasi pembuatan PCR mix, menjalankan thermal cycler dan dilanjutkan pembacaan hasil PCR di gel agarose. Peningkatan nilai pretest dan post test terjadi pada seluruh peserta dengan rerata pretest $44,4 \%$ (nilai terendah $10 \%$ dan tertinggi $70 \%$ ) meningkat menjadi $83.33 \%$ (nilai terendah 70 dan nilai tertinggi 100\%). Melihat antusiasme partisipan dalam kegiatan ini maka perlu dilakukan kegiatan serupa pada guru SMA yang belum terpapar dengan kegiatan ini
\end{abstract}

\section{Korespondensi: wardoyo.eh@unram.ac.id}

\section{PENDAHULUAN}

Pengenalan teknik PCR kepada murid SMA memerlukan teknik tersendiri dalam mengatasi tantangan-tantangan dalam pengajaran. Apa itu biologi molekuler? Untuk apa kita harus mempelajari ini?

PCR pertama kali diperkenalkan oleh Dr. Kary Mullis dkk dalam paper tahun 1986selanjutnya menjadi paper yang puluhan juta kali disitasi untuk aplikasi teknik PCR ini dalam berbagai bidang. Peneluan Mullis sebagai penemuan terbesar abad ini. Kegiatan perkenalan teknik PCR dimulai dari pengajaran teori terkait manfaat, teknik dan prospek kedepan teknik PCR. Dilanjutkan dengan praktek PCR mulai dari ekstraksi DNA, PCR sampai dengan pembacaan produk PCR. Meski tidak semua dapat melakukan praktek PCR, diharapkan dengan kelas mini pemahaman ini akan meningkat. Kegiatan pengenalan teknik molekuler ini lazim dilakukan bagi analis kesehatan, dokter yang berminat dan teknisi laboratorium, sementara pada guru biologi SMA, yang berkepentingan untuk mengajarkan hal tersebut belum pernah diselenggarakan di Kota Mataram. 
Pembelajaran teknik PCR pada mahasiswa S1 menghadapi tantangan yang menarik: karena diajarkan pada semester awal butuh landasan teori yang kuat semasa SMA, teknik PCR merupakan teknik aplikasi biomolekuler dan mempergunakan reagen yang cukup mahal. Menngingat pentingnya pengetahuan mengenai teknik ini, kami mengajukan pengenalan PCR bagi guru biologi SMA di Kota Mataram.

\section{METODE KEGIATAN}

Pelaksanaan kegiatan dilakukan dalam bentuk ceramah dikelas dan demonstrasi teknik PCR dilaboratorium. Peningkatan pemahaman diukur menggunakan model pretest dan post test.

Sebanyak 20 Guru Biologi SMA diajarkan teknik PCR dikelas, didahului dengan pre test dan sisusul dengan materi ekstraksi DNA dan optimasinya, pengukuran konsentrasi DNA, teknik PCR konvensional: denaturasi, annealing dan extension/elongation, primer development, protocol development dan pembacaan PCR.

Demonstrasi Teknik PCR dilakukan di laboratorium molekuler FK Unram dengan dibagi 4 kelompok masing-masing 5 orang. Masing-masing kelompok akan melihat dilakukannya PCR dengan teknik PCR konvensional menggunakan mesin Thermal Cycler. Diakhir demonstrasi dilakukan diskusi tanya jawab dan post tes

\section{HASIL DAN PEMBAHASAN}

Pengabdian kepada masyarakat ini dilakukan pada hari Sabtu, 31 Agustus 2019 di Ruang Sidang Fakultas Kedokteran Universitas Mataram. Sebanyak 20 guru biologi SMA di Kota Mataram di undang dalam pengenalan teknik biologi molekuler ini, dan dihadiri oleh 12 orang guru dengan 10 guru perempuan dan 2 guru laki-laki. Pada awal acara, dibuka oleh ketua panitia dr. E. Hagni Wardoyo dan dilanjutkan dengan pretest dan dipandu oleh dr. Dewi Suryani. Sebelum dimulai pemberian materi, diberikan doorprize flashdisk bagi guru biologi peraih pretest tertinggi dengan nilai $70 \%$.

Pemberian materi diberikan oleh dr. Yunita Sabrina, Ph.D secara interaktif. Susunan presentasi dimulai dengan pengenalan materi genetik, replikasi DNA, dogma sentral dan teknik PCR mulai dari ekstraksi DNA, siklus PCR dan diakhiri dengan pembacaan produk PCR. Dilanjutkan dengan pemutaran video penjelasan terkait dengan penjelasan PCR yang dihantarkan oleh dr. Hagni. Dalam presentasi ini terjadi interaksi intens dengan peserta, mulai dengan dasar-dasar pertanyaan terkait dengan identifikasi kelainan genetik, identitas jenazah tidak dikenal dalam bencana. Peserta yang paling aktif dihadiahi doorprize jatuh pada guru biologi SMA Saraswati. 


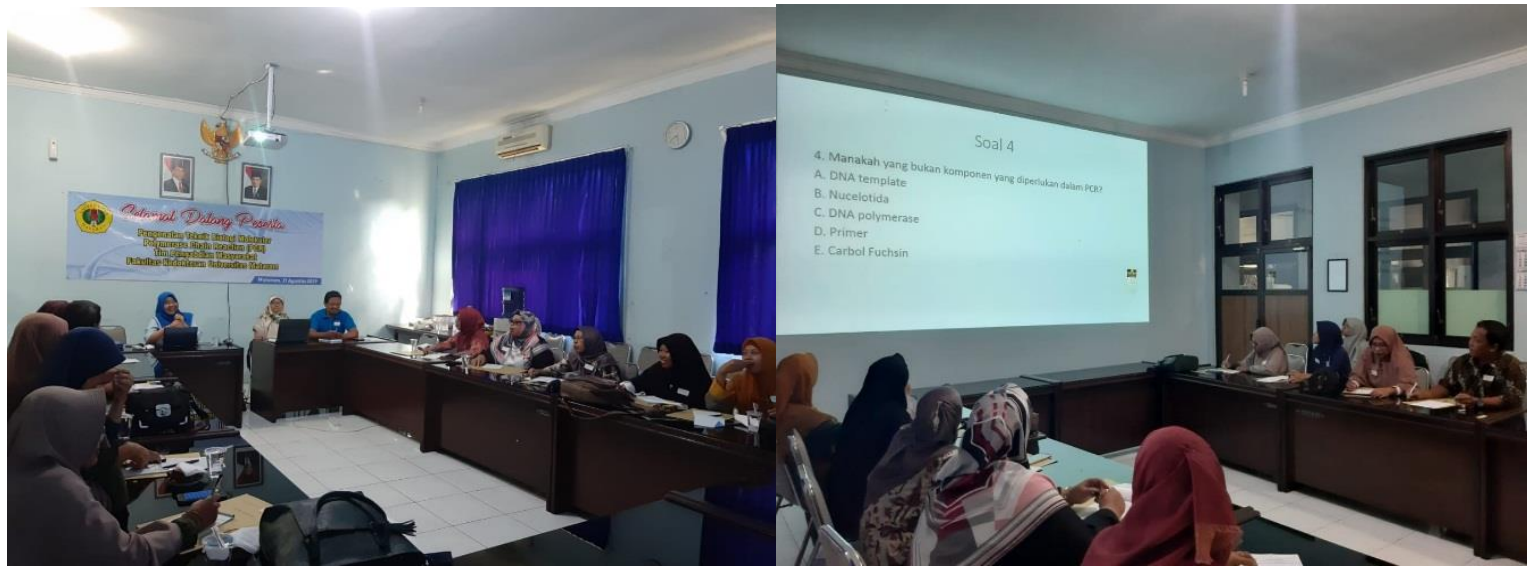

Gambar 1. Suasana ceramah pengenalan teknik biologi molekuler polymerase chain reaction (PCR) di FK Unram

Setelah ceramah dilanjutkan dengan coffee break dan persiapan demonstrasi laboratorium. Demonstrasi laboratorium didahului dengan safety briefing oleh Indah Retnowati Amd.AK. Safety briefing yang diberikan merupakan cara bekerja aman dan selamat bagi peserta dan jalur evakuasi jika terjadi bencana.

Demonstrasi PCR dipandu oleh Ima Malawati, S.Pt., M.Sc yang sebelum dimulainya demo peserta dijelaskan mengenai hal dasar terkait penggunaan mikro pipet agar ketika mencampurkan komponen bahan volumenya tepat. Kemudian selanjutnya peserta dijelaskan dan diminta mencatat PCR master mix yang dibutuhkan. Setelah demo dilakukan, para peserta diminta untuk mencampurkan bahan-bahan yang dibutuhkan ke dalam tabung PCR yang disediakan.

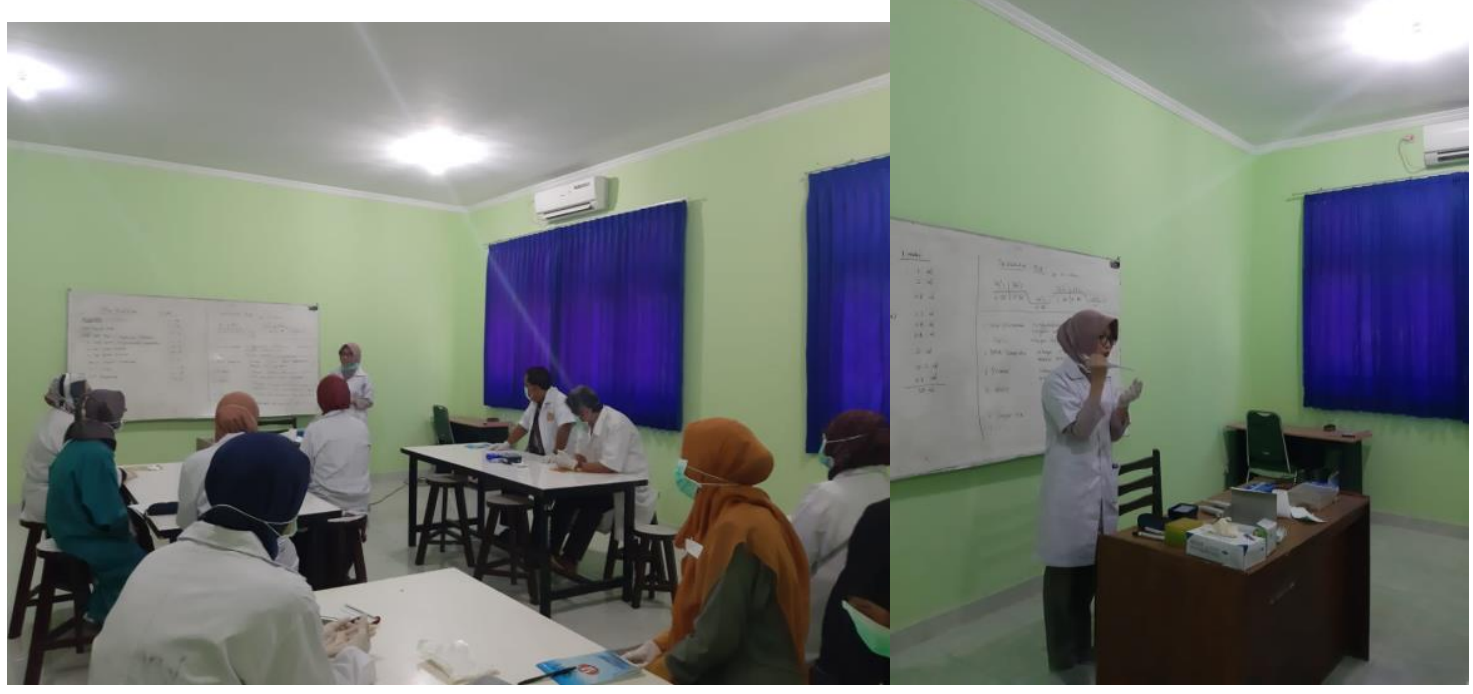

Gambar 2. Suasana demonstrasi laboratorium

Formula PCR master mix yang dicontohkan adalah sebagai berikut: $1 \mu$ template DNA, $1 \mu 1$ 10x buffer PCR, 0,8 $\mu 150 \mathrm{mM} \mathrm{MgCl} 2,1,2 \mu 110 \mathrm{mM}$ dNTP, 0,8 $10 \mu \mathrm{M}$ primer forward, $0,8 \mu \mathrm{M}$ primer riverse, $2 \mu \mathrm{l}$ DMSO, 10,2 $\mu \mathrm{l}$ steril water dan 0,2 $\mu \mathrm{l}$ enzim DNA polimerase. Komponen bahan tersebut adalah untuk membuat final volume $20 \mu$ l. Sedangkan untuk program PCR yang di jelaskan adalah pre denaturasi 3 menit pada suhu $94^{\circ} \mathrm{C}$, denaturasi suhu $94^{\circ} \mathrm{C}$ selama 30 detik, annealing $60^{\circ} \mathrm{C}$ 
selama 30 detik, ekstensi $72^{\circ} \mathrm{C}$ selama 60 detik dan final ekstensi $72^{\circ} \mathrm{C}$ selama 7 menit yang diakhiri dengan $4^{\circ} \mathrm{C}$ sampai sampel diangkat, dengan 25 siklus.

Setelah peserta mengetahui dan mempelajari bagaimana mesin PCR bekerja atau yang biasa disebut thermal cycler selanjutnya peserta mencoba memvisualisasikan hasil PCR dengan melakukan elektroforesis gel agarose. Pada tahap ini, peserta diminta untuk melakukan loading sampel pada masing-masing sumuran gel yang tersedia. Elektroforesis dilakukan selama 20 menit. Selanjutnya hasil elektroforesis dilihat diatas sinar UV menggunakan UV Transluminator dan peserta diminta untuk mendokumentasikan hasil elektroforesis.

Seluruh peserta diminta untuk kembali kekelas untuk menjalani post test dan makan siang. Kembali peserta dengan nilai post test tertinggi, peserta dengan selisih post test-pretest tertinggi mendapatkan doorprize berupa flashdisk dari panitia.

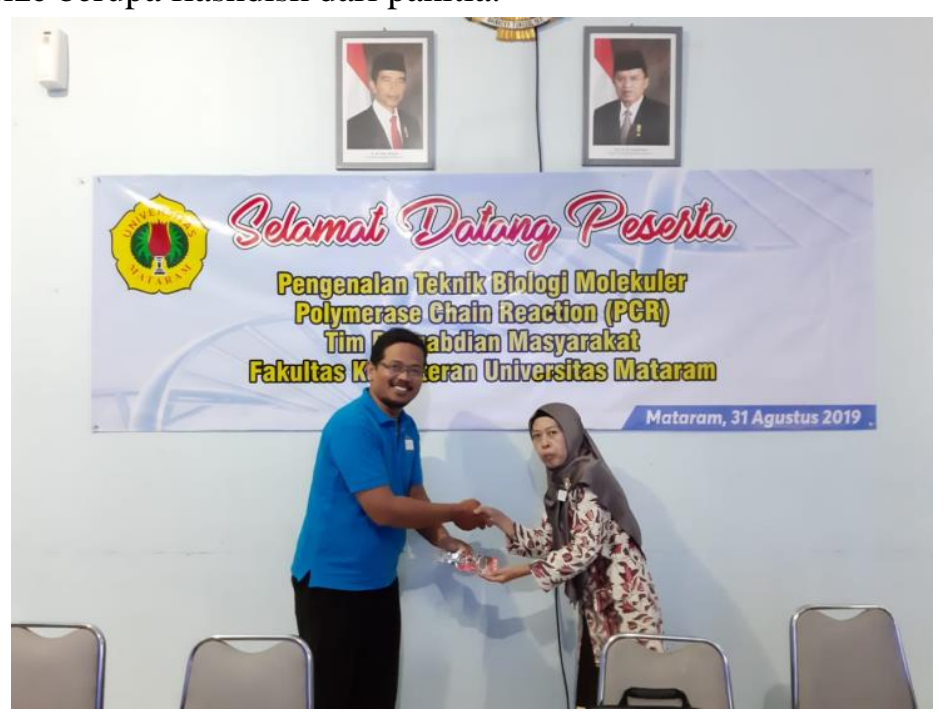

Gambar 3. Pemberian doorprize untuk guru dengan nilai posttest tertinggi.

Peningkatan nilai post test dibandingkan pre test terjadi pada seluruh peserta. Rerata nilai pretest $44,4 \%$ (nilai terendah $10 \%$ dan tertinggi $70 \%$ ) meningkat menjadi $83,33 \%$ (nilai terendah 70 dan nilai tertinggi 100\%). Dari survey persepsi yang dibagikan kepada peserta, $100 \%$ peserta menyatakan kepuasannya dalam mengikuti pelatihan ini dan berharap akan adanya tindak lanjut setelah pelatihan ini. Dan juga melihat antusiasme partisipan dalam kegiatan ini maka perlu dilakukan kegiatan serupa pada guru SMA yang belum terpapar dengan kegiatan ini.

\section{KESIMPULAN DAN SARAN}

Peningkatan nilai pretest dan post test terjadi pada seluruh peserta dengan rerata pretest $44,4 \%$ (nilai terendah $10 \%$ dan tertinggi $70 \%$ ) meningkat menjadi $83.33 \%$ (nilai terendah 70 dan nilai tertinggi 100\%). Melihat antusiasme partisipan dalam kegiatan ini maka perlu dilakukan kegiatan serupa pada guru SMA yang belum terpapar dengan kegiatan ini.

\section{Ucapan Terima Kasih}

Penulis menyampaikan terimakasih kepada Lembaga Penelitian dan Pengabdian Kepada Masyarakat (LPPM) Universitas Mataram yang membiayai pengabdian ini dengan surat perjanjian No. 2226/UN18/LPPM/2019 tanggal 2 Mei 2019 


\section{DAFTAR PUSTAKA}

Kary B. Mullis (1990). The Unusual Orign of the Polymerase Chain Reaction. Scientific American. April. Pp:56-65

Ehtisham M., Wani F, Iram Wani I, Kaur P, Sheeba Nissar. Polymerase Chain Reaction (PCR): Back to Basics. Indian Journal of Contemporary Dentistry, July-December 2016, Vol.4, No.2 DOI: 10.5958/2320-5962.2016.00030.9

Gaurav Solanki (2012) Polymerase Chain Reaction. IJPR 2 (3) 